УДК 94:327.5+327(477)«1992/2021»

\title{
ПЕРЕМИБІДА Д.О.
}

https://orcid.org/0000-0001-7468-4060

ПАСТУХОВ В.В.

https://orcid.org/0000-0002-5485-5827

https://doi.org/10.33577/2313-5603.36.2021.86-99

\section{УКРАЇНА - НАТО: ІСТОРІЯ ВІДНОСИН ТА ЗЛАМ СТЕРЕОТИПІВ В УКРАЇНСЬКОМУ СУСПІЛЬСТВІ ЩОДО АЛЬЯНСУ}

У статті розглядається історичний аспект зміни суспільно-політичної думки щодо співпраці України з Організацією Північноатлантичного альянсу, злам нав'язаних радянською владою та російським інформаційним втручанням стереотипів щодо НАТО та участі Збройних Сил України у спільних миротворчих операціях. На підставі документальних даних доведено, що політика української влади щодо відносин з НАТО не була послідовною, а українське суспільство тривалий час перебувало в полоні колишніх уявлень про цю безпекову організацію. В умовах триваючої агресії Російської Федерації воєнно-технічна, матеріальна, експертна допомога НАТО дуже важлива для України. Нові підходи до забезпечення ефективних гарантій суверенітету, територіальної цілісності та зміцнення обороноздатності країни вимагають активного співробітництва між нашою державою та Альянсом.

Ключові слова: Україна - НАТО, стереотипи, безпека, Збройні Сили України, стратегічне партнерство.

Актуальність проблеми. Для активної протидії російським мілітарним зазіханням наша держава потребує ефективного співробітництва 3 найбільш видатною безпековою організацією сучасного світу - Північноатлантичним альянсом. Анексія Криму та російсько-українська війна на Сході України стимулювали військово-політичні відносини 3 країнами - членами НАТО. Сьогодні метою НАТО є колективне продукування і реалізація дієвої політики в галузі воєнної безпеки. В умовах російської агресії країни - члени Альянсу йдуть курсом посилення військової та політичної допомоги Україні, насамперед у вирішенні проблем 3 модернізацї озброєння, військової техніки та наданні

Перемибіда Денис Олександрович, начальник науково-дослідної лабораторії Наукового центру Сухопутних військ Національної академії сухопутних військ імені гетьмана Петра Сагайдачного, м. Львів.

Пастухов Віктор Вікторович, науковий співробітник науково-дослідної лабораторії Наукового центру Сухопутних військ Національної академії сухопутних військ імені гетьмана Петра Сагайдачного, м. Львів.

(С) Перемибіда Д.О., Пастухов В.В., 2021 
експертної допомоги, а також у проведенні спільних навчань. Отже, головним напрямом практичної співпраці з НАТО стала оборонна галузь, а для країн - учасниць блоку актуалізувалася концепція стримування Росії.

Стратегічне партнерство України з членами Альянсу дозволяє посилити результативність ії дій на міжнародній арені. Воно грунтується на визнанні спільних цілей та завдань безпекового характеру. Нині використання співробітництва 3 партнерами i союзниками у військовій сфері, впровадження стандартів НАТО в Українські збройні сили є не тільки актуальним напрямом державного розвитку, але й компонентом загальноісторичного процесу євроатлантичної інтеграції України.

Аналіз джерел $i$ літератури. Загальні питання військового співробітництва України з Північноатлантичним альянсом розглядалися вже у багатьох дослідженнях як вітчизняних, так і закордонних науковців. До теми військового співробітництва України 3 НАТО зверталися С. Волощук, С. Ліпкевич, Ю. Бураков, Н. Андріянова, Л. Алексієвець та ін. Так, Лесею і Миколою Алексієвець предметно висвітлено політичний дискурс відносин нашої держави з НАТО та запропоновано періодизацію їх становлення. Досить грунтовно питання партнерства 3 Альянсом досліджені у працях В. Бондаренка, С. Речича, Ю. Недзельського, О. Соскіна. У колективній монографії за загальною редакцією О. Соскіна «Вступ до НАТО - стратегічний вибір України» проаналізовано процес еволюції блоку й організаційні аспекти співробітництва $з$ ним.

Метою статті є дослідити чинники, які впливали на розвиток відносин з НАТО від часу незалежності України; показати трансформацію суспільної думки та злам стереотипів щодо співробітництва з Альянсом.

Основна частина. У 1946 р. метою створення Північноатлантичного альянсу (НАТО) було вирішення наступних завдань: оборона перед можливим нападом СРСР та його союзників, утримання військової присутності США в Європі, яке було гарантією оборони західних союзників, і недопущення відродження військової могутності Німеччини, яка стала причиною двох світових воєн. 
Кінець СРСР означав зникнення джерела небезпеки, і це породило дискусії, чи потрібен військовий альянс у світі, що змінився. Після припинення існування прорадянського військовополітичного блоку - Організації Варшавського Договору, його історичний противник - Північноатлантичний альянс, пристосовуючись до нових геополітичних умов та зважаючи на нові виклики у галузі глобальної безпеки, зазнав глибоких трансформаційних процесів, які визначили сучасну його сутність. В оприлюдненій на Римському саміті (1991р.) Стратегічній концепції НАТО були викладені основоположні принципи його подальшого функціонування: принцип колективної оборони; принцип діалогу; принцип співробітництва.

У радянську добу, коли вирували «холодна війна» та протистояння НАТО з Організацією Варшавського договору, комуністичне керівництво докладало величезних пропагандистських зусиль, щодо створення образу Північноатлантичного альянсу як ворожого радянським людям агресивного блоку. Не дивно, що в суспільній свідомості українців (як у цілому в багатьох народів колишнього СРСР) були вкорінені негативні стереотипи щодо НАТО.

Незалежність України московськими політиками була сприйнята як зрада, а бажання наблизитись до європейських країн (i, ще гірше, до НАТО!) - як перехід на ворожий бік. «Слід констатувати, що реально «холодна війна» ніколи не припинялася, хоча й була переведена в інше русло. Боротьба буде вестись лише сателітами США з використанням непідконтрольних нікому суб'єктів регіональної політики... Даний шлях реалізується створенням нестабільних гарячих точок по периметру Росії: Україна, прибалтійські держави, повністю підконтрольні США», - наголошували військово-політичні радники кремлівської влади (Эволючия форм, 2015:27). Політичним, дипломатичним, економічним та інформаційним тиском Російська Федерація (РФ) намагалась примусити українське керівництво відмовитись від європейського напрямку в майбутньому розвитку країни, затягуючи іiі спочатку в Співдружність Незалежних Держав (СНД), потім - в Організацію договору про колективну безпеку (ОДКБ), а згодом - у Митний євразійський союз. 
Однак, Постановою Верховної Ради України від 2 липня 1993 р. були ухвалені «Основні напрями зовнішньої політики України», в яких, зокрема, зазначено, що в умовах зникнення блокового протистояння в Свропі пріоритетного значення набуває проблема створення загальноєвропейської структури безпеки на базі чинних міжнародних інститутів, таких як НБСС, РПС, НАТО, ЗЄС. Безпосереднє та повне членство України в такій структурі створюватиме необхідні зовнішні гарантії іiі національної безпеки (BBP, 1993: cm. 379).

Але реальне становлення дипломатичних відносин України 3 НАТО почалося дещо раніше - $з$ січня 1992 р., коли представник України вперше взяв участь у засіданні Робочої групи Ради Північноатлантичного співробітництва. У лютому 1992 р. відбувся перший візит Генерального секретаря НАТО М. Вернера до Києва, а вже 8 липня - візит Президента України Л. Кравчука до штаб-квартири Альянсу. У відповідь на започаткування активного діалогу 19 листопада в українську столицю приїхав 3 візитом головнокомандувач збройних сил блоку генерал Дж. Шалікашвілі (Алексієвець, 2020:130). Відтак, у 1992 р. наша Держава вже отримала статус асоційованого члена в Парламентській асамблеї НАТО, де іï представляла постійна українська делегація. Наступного року, під час перебування в Києві державний секретар США У. Крістофер запропонував Україні долучитися до програми НАТО «Партнерство заради миру».

На початковому етапі була закладена політико-правова база відносин України і НАТО. 19 жовтня 1993 р. Верховна Рада України законодавчо закріпила варіант Воєнної доктрини України, яка розроблялася відповідно до положень «Основних напрямів зовнішньої політики». Зазначалося, що Україна як європейська позаблокова держава здійснює відкриту зовнішню політику та прагне співпраці з усіма зацікавленими партнерами, уникаючи залежності від окремих держав чи міжнародних структур ( $B B P$, 1993, cm. 409). Водночас наявність терміна «позаблоковий статус» у документі згодом дало підгрунтя опонентам вступу України до Альянсу в їхніх запереченнях стосовно курсу євроатлантичної інтеграції (Ліпкевич, 2007:90).

Найбільш значущою подією у відносинах нашої країни 3 Альянсом стало підписання 8 лютого 1994 р. Міністром закордонних справ України рамкового документа програми «Партнерство 
заради миру» (ПМЗ). Для країн-кандидатів щодо вступу в НАТО були встановлені спеціальні критерії і вимоги, виконання яких було обов'язковою умовою. Вони були закріплені в рамковому документі на січневому 1994 р. Брюссельському саміті НАТО в програмі «Партнерство заради миру» i «Дослідженні щодо розширення НАТО». 25 травня до штаб-квартири НАТО Україна передала свої презентаційні документи, в яких були визначені політичні цілі участі України та низка пріоритетних напрямів. Наша країна стала першою 3 країн СНД, яка приєдналась до «ПЗМ» (Свроатлантична інтеграчія, 2020).

Перша Індивідуальна програма партнерства між Україною i НАТО була прийнята у червні 1995 р., коли Альянс і МЗС України обмінялися відповідними листами, а у вересні того ж року вона була офіційно схвалена на спеціальному засіданні Північноатлантичної Ради НАТО. Завдяки цій програмі було реалізовано низку важливих ініціатив; між Україною та Альянсом були відкриті офіси зв'язку України у штаб-квартирі НАТО і координаційні центри партнерства. У першому кварталі 1996 р. був ухвалений спільний документ «Реалізація розширення та поглиблення відносин між Україною і НАТО» (Хронологія відносин, 2019). Після прийняття рішення про створення в Києві Центру інформації та документації НАТО почалась активна інформаційна діяльність щодо натовсько-українських відносин. Незважаючи на це, більшість громадян України з упередженням ставились до співпраці України з Альянсом.

1996 р. також характеризувався активною роботою української влади по просуванню інтересів Держави у відносинах з НАТО, зокрема у плані встановлення відносин «особливого партнерства». 31994 р. військові підрозділи ЗС України брали участь у спільних 3 Альянсом заходах, а 1996 . провели на українській території багатонаціональні військові навчання «Щит миру». Водночас слід зауважити, що керівництво держави не забезпечило необхідної інформаційної складової для формування підтримки народом країни євроінтеграційних прагнень та вступу в Альянс. Навіть центральний друкований орган Міністерства оборони України присвячував «Партнерству заради миру» тільки коротенькі публікації, які містили мінімум інформації (Ліпкевич, 2007:91). Найбільше прихильників вступу до НАТО 
виявилося серед студентів та громадян $з$ вищою освітою. Разом i3 тим російські пропагандисти та їх українські прибічники стверджували, що Північноатлантичний альянс ставить за мету просунути свою інфраструктуру на схід та нарощувати військову присутність поблизу російських кордонів. Такі твердження, безумовно, впливали на український соціум.

Особливим для розвитку співпраці і відносин 3 Альянсом виявився наступний рік. Влітку 1997 р. у Мадриді відбувся саміт глав держав - членів НАТО. Саміт підніс українсько-натовські відносини на якісно новий рівень. 9 липня 1997 р. між Україною і Альянсом був підписаний документ величезного політичного значення - Хартія про особливе партнерство (від імені України президентом Л. Кучмою, від імені НАТО - генсеком Х. Солано), який досі залишається базовим документом, що визначає пріоритети двосторонніх відносин. У Хартії були прописані головні зобов'язання сторін щодо розвитку особливого партнерства i співпраці. Вона затвердила принципи та інструменти зміцнення взаємодії України з Альянсом, визначила напрями співробітництва (Алексієвець, 2020:132). Одним з головних досягнень на цьому шляху було створення консультативного механізму, спільних робочих груп. Для взаємного контролю за виконанням Хартії діяла комісія Україна - НАТО, яка збиралася не рідше ніж двічі на рік.

У той же час Україна опинилась між двома колишніми запеклими геополітичними противниками: на західному кордоні реальною стала поява нових членів Альянсу (Польща, Угорщина, Чехія), а на східному були країни - учасниці ОДКБ. На запрошення Президента України у 1998 р. до Києва з офіційним візитом приїхав Генеральний секретар НАТО Х. Солана, а наприкінці року Л. Кучма затвердив державну програму співробітництва України з НАТО на період до 2001 р. (Хронологія відносин, 2019). 23 квітня 1999 р. Верховна Рада ухвалила Постанову «Щодо відносин України і Організації Північноатлантичного договору (НАТО)» (Хронологія відносин, 2019). Цей документ зазначав, що стратегічною метою України є повномасштабна інтеграція до євроатлантичних структур і повноправна участь у системі загальноєвропейської безпеки. 
Російська Федерація, яка на цей момент розпочала другу російсько-чеченську війну, звинувачувала НАТО у початку воєнного конфлікту в Югославії. Засоби масової інформації гучно повідомляли про бомбардування югославської території у ході операції Альянсу, а українська влада прогавила момент особливої потреби інформувати громадськість про те, що справді відбувається на Балканському півострові, про роль НАТО 3 підтримки миру під проводом ООН та чому Україна прагне інтеграції в структури Альянсу.

Антизахідне налаштування суспільства, яке наполегливо насаджувалося певними політичними колами як в РФ, так і в Україні, підтримувало вкорінені у свідомість людей негативні стереотипи, що НАТО - агресивний військовий блок, ворожий слов'янському світу. Недостатність належного інформаційного забезпечення заходів партнерства 3 Альянсом та відсутність достатніх відомостей про реальний стан справ не сприяли формуванню відповідної позитивної громадської думки щодо співпраці України з блоком. Голова Комітету Верховної Ради 3 питань нацбезпеки і оборони Г. Крючков заявив: «Президент, підпорядковані безпосередньо йому зовнішньополітичне та інші відомства, не рахуючись $з$ парламентом, усупереч волі переважної більшості нашого народу нав'язали Україні фактично прозахідну, пронатовську орієнтацію, несумісну з іiі нейтральним, позаблоковим статусом» (Ліпкевич, 2007:92). У 2000 р. майже половина населення України вважала НАТО агресивним військовим блоком, водночас багато хто був упевнений, що участь у програмі «Безпека заради миру» буде на користь Українській державі та зміцнить іï безпеку. Незважаючи на різноманітні перешкоди, у 2002 р. Україна вперше офіційно продекларувала свій намір вступу в Альянс.

Динаміка розвитку співпраці України та НАТО відповідно до Хартії про особливе партнерство була наповнена конкретним змістом, але в середині 2004 р. поступ до НАТО було згорнуто. Вважається, що причиною тому були складні внутрішньополітичні процеси в Україні. Отже, рішення про залучення нашої держави до офіційних програм підготовки до членства в НАТО на Саміті НАТО у Стамбулі (29 червня 2004 р. ) прийнято не було (Хронологія відносин, 2019). 
Якщо європейський вибір України, їі зближення з ЄС і НАТО викликали роздратування військово-політичних кіл РФ, то «помаранчева революція» 2004 р. всерйоз стурбувала російське керівництво. За президентства В. Ющенка українсько-натовські відносини набули значного посилення у бажанні інтеграції 3 Альянсом. Діалог $з$ питань набуття членства в НАТО був започаткований комісією Україна-НАТО у Вільнюсі в квітні 2005 р. В рамках участі у «ПЗМ» Україна була єдиною країною-партнером, яка відзначилась у всіх основних миротворчих місіях під проводом НАТО: у складі Міжнародних сил безпеки в Косово, Афганістані, Іраку, була учасницею антитерористичної операції НАТО «Активні зусилля» (Украӥна-НАТО, 2011:31). Реалізація військового співробітництва 3 НАТО була благотворною в контексті підвищення рівня боєздатності ЗСУ і дозволяла нарощувати оперативні спроможності української армії.

Чільне місце у кремлівських інсинуаціях того часу займає залякування «американським пануванням» та експансією НАТО. Наприклад, навчання «Сі-Бриз» російська пропаганда представляла як підготовку до розгортання військової бази НАТО на Кримському півострові. Наслідком стали акції протесту жителів Криму проти проведення «Сі-бриз» у 2006 р. і наступних роках, ініційовані українськими лівими та проросійськими силами. Застосовуючи стереотипні твердження, що вступ до НАТО погіршить стосунки з Росією, Верховна Рада Криму проголосувала за рішення щодо оголошення півострову територією без НАТО. Промовистим був той факт , що в червні 2006 р. тодішній прем’єр-міністр України В. Янукович на засіданні Комісії Україна - НАТО вніс пропозицію тимчасово відкласти питання про переведення відносин з Альянсом на рівень Плану дій щодо членства (ПДЧ), прив'язавши його до більш-менш широкої підтримки суспільства. Тоді держави - члени НАТО висловились про важливість рівня громадської підтримки ідеї членства в Альянсі.

Питання щодо приєднання України до Плану дій по отриманню членства в організації було дуже важливим у розвитку відносин із НАТО. Перший крок був зроблений з боку Альянсу, який заявив, що НАТО очікує формального звернення від нашої 
Держави про бажання приєднатись до ПДЧ (Артьомов, 2008:19). Українське керівництво звернулось до генсека НАТО з проханням на саміті Альянсу в Бухаресті (квітень 2008 р.) підтвердити приєднання України до ПДЧ. Реакція Москви на це звернення була дуже роздратованою. Керівник російського МЗС С. Лавров наголосив, що подальша співпраця Росії та України, зокрема й у військовій сфері, буде прямо залежати від розвитку стосунків останньої з НАТО. Незважаючи на високу оцінку союзників участі України у миротворчих операціях під проводом НАТО та iii внеску у загальну безпеку, на бухарестському саміті Україна отримала відмову у ПДЧ через вплив Росії та опір внутрішньої української опозиції.

Можна побачити, що 2005 - 2009 рр. стають піком євроатлантичних устремлінь України, які мали бути реалізовані через Річні національні програми, а російсько-грузинська війна 2008 р. активізувала пронатовські настрої в Україні.

Водночас мало місце й скасування двосторонніх і багатосторонніх заходів, запланованих у межах програми співробітництва України з НАТО, що відбувалося внаслідок непримиренного протистояння влади й опозиції 3 питання розвитку відносин 3 Альянсом. Підгрунтям напруги було й запровадження програми «Східне партнерство» у 2009 р., членами якої стали, крім України, Грузія, Молдова, Азербайджан, Свропейський Союз (Бураков, 2019:112). Частина українських політиків вимагала суттєвого посилення співробітництва України з ОДКБ. Громадян країни запевнювали, що без російської допомоги Україну очікує політичний та економічний хаос. Проте військові експерти підкреслювали, що країна не входить до геополітичної зони відповідальності ОДКБ, оскільки ця організація створювалася РФ та середньоазійськими республіками колишнього СРСР, a іï стратегічна мета - захист російських інтересів і російської військової присутності у Середній Азії (Александров, 2011:15).

2010 рік став найбільш провальним в євроінтеграційному поступі України. Перемога В. Януковича на президентських виборах, відкинула відносини з Альянсом на рівень «конструктивного партнерства». 1 липня 2010 р. Верховна Рада України прийняла закон «Про засади внутрішньої і зовнішньої політики» $(B B P, 2010: c m .527)$, відповідно до якого було проголошено 
позаблоковий статус нашої Держави. Це стало кардинальним переглядом підходів до розвитку відносин між Україною та НАТО. Зміна формату відносин була зумовлена політикою Партії регіонів та президента В. Януковича, який цілковито підтримував позиції Кремля. Зазначалось, що легалізація операцій НАТО по реагуванню на конфлікти за межами традиційної зони відповідальності Альянсу може викликати негативні наслідки для безпеки України (Александров, 2011:7). Найвагомішим чинником, що стримував співробітництво між Україною і НАТО був політичний тиск з боку ОДКБ.

Відмовившись від прагнення до членства в НАТО, Україна все ж таки продовжувала взаємовідносини і співробітництво 3 цим військово-політичним блоком. Так, у другій половині 2013 р. фрегат ВМС України «Гетьман Сагайдачний» 3 групою спеціального призначення взяв участь в антипіратській операції НАТО в Аденській затоці.

Коли Росія, нехтуючи міжнародним правом, анексувала український Крим, а потім розпочала інтервенцію на Сході України, вона активно використовувала стереотип «владу в Україні захоплюють неонацисти і націоналісти». Однак, українське суспільство і міжнародна спільнота вже на власні очі побачили реальні наслідки таких маніпуляцій. Стереотип «братнього народу» був зруйнований.

2 березня 2014 р. відбулось екстрене засідання Комісії Україна - НАТО, в ході якого члени Альянсу висловили одноголосну підтримку нашій країні та засудили дії РФ. Практична співпраця НАТО з РФ була припинена. 29 грудня 2014 р. тодішній президент України П. Порошенко підписав закон, яким було скасовано позаблоковий статус України.

Важливим у плані зміцнення обороноздатності України став Варшавський саміт НАТО у липні 2016 р., на якому Україні було надано «Комплексний пакет допомоги», що підтвердило взаємодію Альянсу з Україною у сфері безпеки (40 напрямів співпраці). Створена тоді ж Комісія з питань координації євроатлантичної інтеграції України сприяла забезпеченню ефективного співробітництва 3 НАТО через спільні робочі групи 3 воєнної реформи та оборонно-технічного співробітництва (Свроінтеграція, 2020). 
Солідарність з Україною була відзначена і в Декларації брюссельського саміту НАТО у липні 2018 р. Парламентська Асамблея НАТО на сесіях у травні й листопаді 2018 р. підтримала перспективу вступу України до Альянсу.

Якщо у квітні 2012 р. лише 13\% громадян вбачали у вступі до НАТО найкращий варіант безпеки, 31\% віддавали перевагу військовому союзу з Росією і ще $31 \%$ - позаблоковому статусу, то після початку російсько-української війни громадська думка радикально змінилася: вступ до НАТО підтримувало $40-46 \%$ громадян, військовий союз з Росією 5 - 7\%, а прибічниками позаблокового статусу залишалися 21- 28\% (Бураков, 2019:116). Українці переосмислили загрози, які стоять перед державою, i розуміють, у чому, власне, полягає перевага колективної безпеки. 7 лютого 2019 р. Верховна Рада 335 голосами закріпила у Конституції України курс на членство Держави в Європейському Союзі та Північноатлантичному Альянсі.

Україна - єдина країна, яка не будучи членом Альянсу, отримує допомогу, які зазвичай надаються тільки членам блоку. Ефективність спільних військових навчань 3 країнами-членами НАТО була доведена, коли наші Збройні Сили виконували завдання У рамках АТО й ООС на сході країни: високий рівень боєздатності демонстрували саме ті підрозділи, які залучалися до багатонаціональних військових навчань і операцій (Беззуб, 2019).

Висновки. Підсумовуючи, зазначимо, що сучасні відносини України з НАТО пройшли нелегкий та суперечливий шлях. За нинішніх умов, взаємодія нашої Держави з Організацією Північноатлантчного договору, членами якої сьогодні є 30 держав світу, підпорядковується насамперед потребам максимального зміцнення обороноздатності держави та реформування іiі Збройних Сил, наближенню до стандартів Альянсу, що дасть можливість відповідати критеріям, необхідним для приєднання до НАТО. Партнерство України з Альянсом українська сторона розцінює як стратегічне. Керівництво Альянсу незмінно та послідовно підтримує інтереси України у протистоянні російській агресії.

Натовський вишкіл особового складу українського війська, ефективна зброя й якісне надання медичної допомоги - це тільки частина завдань, до реалізації яких рухатимемось через 
співпрацю 3 НАТО. В українсько-натовських відносинах 3 невійськового співробітництві найбільш важливими сферами $€$ інформаційна безпека, кібербезпека, новітні технології, енергетична безпека та стратегічні комунікації. Інтеграційний шлях України в НАТО є тривалим і безперервним процесом, головна мета якого - убезпечити Державу від викликів XXI століття.

\section{Використані посилання}

Александров О. (2011) Украӥна-НАТО: нові умови та реалї співробітництва. Київ, НІСД, 56 с.

Алексієвець Л., Алексієвець М. (2020) Трансформація відносин України та НАТО в 1991 - 2019 рр.: історичний аспект. Украӥнський історичний журнал. № 1. C. $126-142$.

Артьомов І. (2008) Прагнення України приєднатись до ПДЧ і ставлення населення до вступу в НАТО. Взаємовідносини Украӥни з НАТО: соџіальнополітичний аспект. Ужгород, Ліра, С. 23 - 69.

Беззуб І. (2019) Украӥна - НАТО: стан та перспективи взаємовідносин. URL:<nbuviap.gov.ua/index.php?option $=$ com_content $\&$ view $=$ article $\&$ id $=27$ 51:ukraina-nato-stan-a-perspektivi-vzaemovidnosin \&catid=8\&Itemid=350> [Дата звернення 14 липня 2021].

Бураков Ю. (2019) Військово-політичне співробітництво України з Північноатлантичним альянсом на сучасному етапі. Військово-науковий вісник. № 32 . C. $111-119$.

Євроатлантична інтеграиія. (2020) URL: <https://mvs.gov.ua/uk/ministry/ evro-atlantic-integration> [Дата звернення 18 липня 2021].

Ліпкевич С. (2007) Трансформація громадської думки України протягом $1994-2006$ рр. щодо вступу в Північноатлантичний альянс. Військово-науковий вісник. Вип. 9. С. 87-99.

Постанова Верховної Ради України від 2 липня 1993 р. № 3360-ХІІ «Про основні напрями зовнішньої політики України». (1993) Відомості Верховної Ради України (ВВР). № 37. Ст. 379.

Постанова Верховної Ради України від 19 жовтня 1993 р. № 3529-ХІІ «Про Воєнну доктрину України». (1993) Відомості Верховної Ради України (ВВР). № 43. Ст. 409.

Про засади внутрішньої і зовнішньої політики. Закон України від 1 липня 2010 p. № 2441-VI. (2010) Відомості Верховної Ради Украӥни (ВВР). №40. Ст. 527. )

Хронологія відносин Україна - HATO. (2019) URL: <https://ukrainanato.mfa.gov.ua/ukraina-nato/hronologiya-vidnosin-ukraina-nato> [Дата звернення 21 липня 2021].

Эволючия форм, методов и инструментов противоборства в современных конфликтах (2015) Москва, «Экон-Информ», 218 с. 


\section{References}

Alexandrov O. (2011) Ukraine - NATO: new conditions and realities of cooperation. Kyiv, NISS. 56 p. (ukr).

Aleksiievets L., Aleksiievets M. (2020) The transformation of Ukraine - NATO relationships in 1991-2019: a historical aspect. Ukrainian Historical Journal. № 1. P. 126-142. (ukr).

Artyomov I. (2008) Ukraine's desire to join the MAP and the attitude of the population to joining NATO. Ukraine's relations with NATO: socio-political aspect. Uzhhorod, Lyre. 23-69 p. (ukr).

Toothless I. (2019) NATO Ukraine: state and prospects of relations. URL: <nbuviap.gov.ua/index.php?option=com_content\&view=article \&id=2751 :ukraina-natostan-a-perspektivi-vzaemovidnosin\&catid $=8 \& I t e m i d=350>$ [Accessed July 14, 2021] (ukr).

Burakov Yu. (2019) The military political cooperation of Ukraine with the North Atlantic Alliance at the current stage. Military-scientific bulletin. № 32. P. 111-119 (ukr).

Euro-Atlantic integration. (2020) URL: https://mvs.gov.ua/uk/ministry/evro-atlanticintegration [Accessed July 18, 2021] (ukr).

Lipkevich S. (2007) Transformation of Ukrainian public opinion during 1994-2006 on joining the North Atlantic Alliance. Military-scientific bulletin. № 9. P. 87- 99 (ukr).

Resolution of the Verkhovna Rada of Ukraine of July 2, 1993 № 3360-XII "On the main directions of Ukraine's foreign policy". (1993) Information of the Verkhovna Rada of Ukraine. № 37. Art. 379 (ukr).

Resolution of the Verkhovna Rada of Ukraine of October 19, 1993 № 3529-XII "On the Military Doctrine of Ukraine". (1993) Information of the Verkhovna Rada of Ukraine. №43. St. 409 (ukr)

On the principles of domestic and foreign policy. Law of Ukraine of July 1, 2010 № 2441-VI. (2010) Information of the Verkhovna Rada of Ukraine. № 40. Art. 527 (ukr).

Chronology of NATO-Ukraine relations. (2019) URL: https://ukrainanato.mfa.gov.ua/ukraina-nato/hronologiya-vidnosin-ukraina-nato (ukr). [Application date July 21, 2021].

The evolution of forms, methods and tools of confrontation in modern conflicts (2015) Moscow, Econ-Inform. 218 p. (rus).

\section{Peremybida D., Pastukhov V.}

UKRAINE - NATO: HISTORY OF RELATIONS AND FALLING STEREOTYPES IN UKRAINIAN SOCIETY REGARDING TO THE ALLIANCE

Development of relationship between Ukraine and NATO shows that it was difficult and contradictory process. The successful way it got after Russian aggression to Ukraine and the annexation of Crimea. The author historically considers how the socio-political opinion on Ukraine's cooperation with the North Atlantic Alliance, falling stereotypes about NATO and the participation of the Ukrainian Armed Forces in joint military exercises created by the Soviet authorities and Russian information intervention has changed. The progress of relations between Kyiv and the Alliance, difficult transfer from cooperation to strategic partnership are studied. 
Based on documentation, it has been proved that the policy of the Ukrainian authorities regarding relations with NATO was not consistent, and Ukrainian society has long been captivated by the former ideas about this security organization. In the context of Russian aggression, which are continuing, NATO helps with militarytechnical, material and expert assistance to Ukraine. New approaches to ensuring effective guarantees of independence, territorial integrity and strengthening the country's defense capabilities require active cooperation between our country and the Alliance. The special partnership between Ukraine and NATO has proved its viability, historical perspective and has grown into a multifaceted complex of practical cooperation for the European integration processes of the Ukrainian state. Ukraine's priorities in relations with the alliance on the basis of national interests are highlighted. Today, cooperation with partners and allies in the military sphere, the implementation of NATO standards in the Ukrainian armed forces is not only an important area of state development, but also a component of the historical process of Euro-Atlantic integration of Ukraine.

Keywords: Ukraine-NATO, stereotypes, security, Armed Forces of Ukraine, strategic partnership. 